\title{
Kriminologia saa vihdoin oman suomalaisen tieteenalajulkaisun
}

Suomessa on nähty viime vuosina voimakas kriminologian nousu sekä tutkimuksen että opetuksen saralla. Tämän ilmauksena kriminologit perustivat oman tieteenalayhdistyksen, Suomen Kriminologisen Yhdistyksen, vuonna 2019. Yhdistys on jo ehtinyt käynnistää uusia traditioita, kuten vuotuiset Veli Verkko -luennot sekä Kriminologian päivät. Osana kriminologian nousun jatkumoa on luontevaa, että yhdistys on perustanut itselleen oman tieteenalajulkaisun. Käsillä oleva Kriminologia-lehden ensimmäinen numero symbolisoi siten uutta vaihetta vahvan, itsenäisen ja monitieteisen kriminologian kehityksessä. Riippumattoman tieteenalayhdistyksen kustantama Kriminologia-lehti on poliittisesti sitoutumaton, koskien sekä yleistä yhteiskuntapolitiikkaa että kriminaalipolitiikkaa.

Tässä ensimmäisessä lehden numerossa julkaistaan monipuolinen ja erilaisiin tutkimustraditioihin perustuva asiantuntija- ja tutkimuskatsaus ajankohtaisista kriminologisista ilmiöistä. Yhtenä ajankohtaisena aiheena esiin nousee vähemmistöt ja poliisikontrolli. Elsa Saarikkomäki tutkii artikkelissaan etnisten vähemmistönuorten kokemuksia virallisesta kontrollista ja leimaamisesta. Haastatteluaineistoon perustuvan analyysin mukaan nuoret kokevat olevansa epäilyn ja kontrollin alaisena juuri oletetun vähemmistötaustansa takia, jonka seurauksena kontrolli näyttäytyvät heille kielteisenä ja leimaavana. Jukka Savolainen puolestaan pohtii puheenvuorossaan viime aikoina julkisuudessa esillä ollutta oletusta poliisiväkivallan kohdistumisesta erityisesti mustaan väestöön Yhdysvalloissa. Savolainen reflektoi aiheen uutisointia ja tutkimuksellisia mahdollisuuksia tuoden esiin asioiden moninäkökulmaisuuden.

Myös nuorisorikollisuus nousee ajankohtaisena teemana esiin numeron teksteissä. Markus Kaakinen ja Matti Näsi kuvaavat artikkelissaan nuorisorikollisuuden tilannetta vuonna 2020. Aarne Kinnunen puolestaan esittelee puheenvuorossaan nuorisorikollisuustutkimuksen hyödynnettävyyttä Oikeusministeriössä erityisesti rikoksentorjunnan näkökulmasta. Yksi Kinnusen tekstissä korostuva teema on vaikuttavuusarvioinnin vaikeus, joka on keskeisenä teemana myös Sasu Tynin ja Mikko Aaltosen artikkelissa. He tarkastelevat vankeusaikaisten kuntoutusohjelmien vaikutusarviointeja ja arvioitavuutta esitellen myös monipuolisesti olemassa olevia vankilatoiminnan ohjelmia. Osittain samaan teemaan kytkeytyy myös Mikko Aaltosen puheenvuoro, jossa hän tarkastelee kriminologisen rekisteritutkimuksen kehityssuuntia. Aaltonen tuo esiin rekisteritutkimuksen mahdollisuuksia juuri vaikuttavuustutkimuksissa mutta myös laajemmin kriminologisissa kysymyksissä.

Numeron neljännessä artikkelissa korostuu teorianäkökulma. Vilma Niskanen ja Petteri Pietikäinen hyödyntävät artikkelissaan kriminologisen tutkimuksen aatehistoriallista menetelmää tarkastellessaan sosiaalisen disorganisaation käsitteen ja teorian alkuperää Chicagon sosiolo- 
gisen koulukunnan tutkimuksissa 1918-1948. Numero päättyy Emma Villmanin monipuoliseen kirja-arvioon alkuvuodesta 2021 julkaistusta Sakari Kainulaisen ja Juho Saaren toimittamasta kirjasta Suomalainen vanki.

Kuten ensimmäisen numeron kokonaisuudesta käy ilmi, on Kriminologia-lehti tarkoitettu laajasti kriminologisen tutkimuksen ja keskustelun foorumiksi. Lehdessä kriminologia hahmotetaan sekä itsenäisenä tieteenalana että monitieteisenä tutkimuskenttänä. Lehti haluaa jatkossakin toimia kanavana erilaisten traditioiden piiristä tulevalle rikollisuuden ja kontrollin tutkimukselle. Näin luodaan myös kriminologisen tutkimuskentän yhtenäisyyttä ja identiteettiä. Kriminologian moninainen kenttä edellyttää, että Kriminologia-lehdellä on jatkossakin oma toimituksellinen linjansa, jossa erilaisista traditioista tulevaa tutkimusta ja keskustelua voidaan käydä samojen periaatteiden mukaisesti. Tämä on Kriminologia-lehdelle haaste ja mahdollisuus. Yhdenmukaisen alustan kautta erilaiset näkökulmat pääsevät tavoittamaan yhteisen lukijakunnan ja keskustelemaan keskenään. Tästä hyötyy laajasti suomalainen kriminologinen ja kriminaalipoliittinen tutkimus, keskustelu ja päätöksenteko.

Vielä lopuksi haluamme kiittää kaikkia Kriminologia-lehden perustamiseen ja sen ensimmäiseen numeroon osallistuneita kirjoittajia, vertaisarvioijia, toimituksen, toimitusneuvoston ja Suomen Kriminologisen yhdistyksen jäseniä sekä kaikkia muita prosessin eri vaiheissa tukensa antaneita kollegoita. Samalla rohkaisemme kriminologian kentän eri toimijoita jatkossakin tarjoamaan tutkimustaan ja ajatteluaan julkaistavaksi uuteen yhteiseen tieteenalajulkaisuumme.

Noora Ellonen, ensimmäisen numeron vieraileva päätoimittaja

Markus Kaakinen, päätoimittaja

Janne Kivivuori, toimitusneuvoston puheenjohtaja 